\title{
Autoayuda y efectividad en la prescripción y uso de las ayudas técnicas en personas con discapacidad
}

Muñoz C, Miranda O, Veliz V, Martinez D.

\begin{abstract}
- Resumen
Este trabajo desarrolla una reflexión acerca del concepto de la autodeterminación de las personas con discapacidad, y las decisiones que le son accesibles dentro de los procesos de integración social. Ello se realiza a partir del estudio de dos casos paradigmáticos, con relación a la decisión del uso de ayudas técnicas. El modelo rehabilitador y el paradigma de la autonomía personal conciben dos maneras distintas de enfrentar la problemática de la integración y participación de personas con discapacidad y por consecuencia, de cada uno se desprenden dos maneras de reconstruir la ocupación. Los equipos de salud son los llamados a guiar y provocar procesos adaptativos, los cuales pueden llevarse a cabo a través de muchos caminos.
\end{abstract}

\begin{abstract}
- Abstract
This work develop a reflection about the selfdeteminaton concept in handicapped people and the possibilities of decision in the social integration process. This is done since the study of two paradigmatic cases, about the decision of the use of technical aids. The rehabilitation model and Ihe autonomy paradigm are two different ways of face the integration and participation problems of handicapped people, and, two ways of occupation reconstruction. The health team are cooled to guide and promote adaptive process which can be done in different ways.
\end{abstract}

Escuela de Terapia Ocupacional, Facultad de Medicina. UNiversidad de Chile

Contacto > > cmunoz@machi.med.uchile.cl 